\title{
Review of the NURE Assessment of the U.S. Gulf Coast Uranium Province
}

\author{
Susan M. Hall ${ }^{1,2}$
}

\begin{abstract}
Received 2 November 2012; accepted 31 January 2013 Published online: 24 March 2013
\end{abstract}

Historic exploration and development were used to evaluate the reliability of domestic uranium reserves and potential resources estimated by the U.S. Department of Energy national uranium resource evaluation (NURE) program in the U.S. Gulf Coast Uranium Province. NURE estimated 87 million pounds of reserves in the $\$ 30 / 1 b \mathrm{U}_{3} \mathrm{O}_{8}$ cost category in the Coast Plain uranium resource region, most in the Gulf Coast Uranium Province. Since NURE, 40 million pounds of reserves have been mined, and 38 million pounds are estimated to remain in place as of 2012, accounting for all but 9 million pounds of $\mathrm{U}_{3} \mathrm{O}_{8}$ in the reserve or production categories in the NURE estimate. Considering the complexities and uncertainties of the analysis, this study indicates that the NURE reserve estimates for the province were accurate. An unconditional potential resource of 1.4 billion pounds of $\mathrm{U}_{3} \mathrm{O}_{8}, 600$ million pounds of $\mathrm{U}_{3} \mathrm{O}_{8}$ in the forward cost category of $\$ 30 / 1 b \mathrm{U}_{3} \mathrm{O}_{8}$ (1980 prices), was estimated in 106 favorable areas by the NURE program in the province. Removing potential resources from the non-productive Houston embayment, and those reserves estimated below historic and current mining depths reduces the unconditional potential resource $33 \%$ to about 930 million pounds of $\mathrm{U}_{3} \mathrm{O}_{8}$, and that in the $\$ 30 / \mathrm{lb}$ cost category $34 \%$ to 399 million pounds of $\mathrm{U}_{3} \mathrm{O}_{8}$. Based on production records and reserve estimates tabulated for the region, most of the production since 1980 is likely from the reserves identified by NURE. The potential resource predicted by NURE has not been developed, likely due to a variety of factors related to the low uranium prices that have prevailed since 1980.

KEY WORDS: Uranium, assessment, Texas, reserve, resource, endowment.

\section{INTRODUCTION}

The uranium endowment of the United States historically was assessed by the U.S. Department of Energy (DOE). Since 1984, the U.S. Geological Survey (USGS) has been responsible for calculating the undiscovered uranium resources for the U.S., while the Department of Energy's Energy Information Administration (EIA) reports uranium reserves and production. A comprehensive review of previous

\footnotetext{
${ }^{1}$ U.S. Geological Survey, Central Energy Resources Science Center, Box 25046, MS 939, Denver CO 80225, USA.

${ }^{2}$ To whom correspondence should be addressed; e-mail: SusanHall@usgs.gov
}

estimates of undiscovered resources is in progress as part of a new USGS assessment of undiscovered domestic uranium resources. The last comprehensive domestic U.S. uranium assessment program, the U.S. Department of Energy's National Uranium Resource Evaluation (NURE) program, was formally completed in 1980; however, some assessments were completed through 1982. The new USGS assessment group is analyzing and georeferencing the results of the NURE program. The Gulf Coast Uranium Province, the western portion of the NURE Coastal Plain Uranium Resource Region, was selected for review of the assessment methodology used in the NURE program as part of the evaluation of potential assessment strategies to adopt for the new assessment (Fig. 1). 


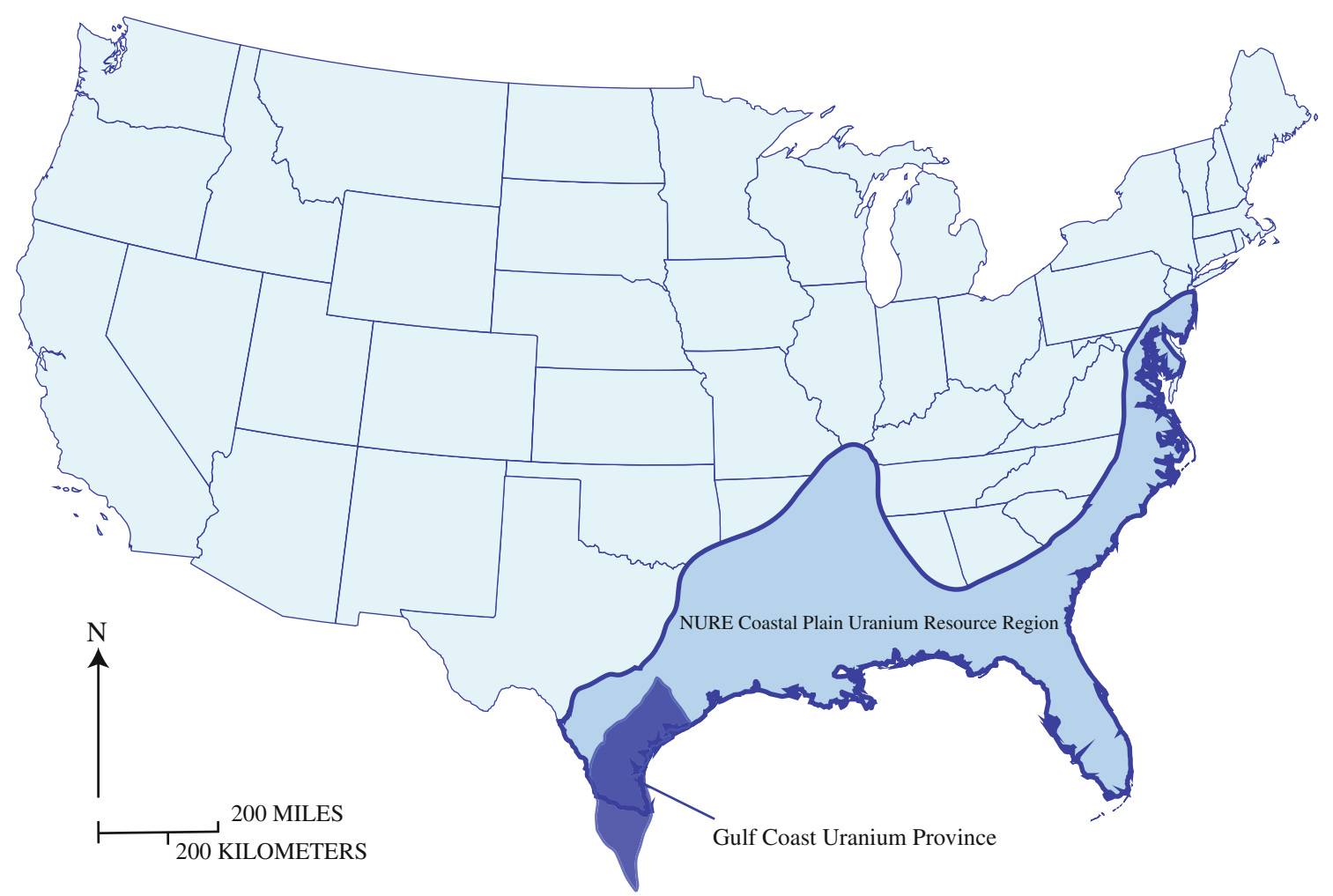

Figure 1. Location of the NURE coastal plain uranium resource region (U.S. Department of Energy 1980) and Gulf Coast Uranium Province (Finch 1996).

This province has been continuously explored and developed since the NURE assessment and this exploration and development data are used here to determine if the uranium in undiscovered resources and in place reserves estimated by NURE were accurate. The accuracy of resource predictions is critical if they are to be relied upon to guide public policy.

\section{URANIUM DEPOSIT MODEL FOR THE GULF COAST URANIUM PROVINCE}

\section{Location}

Uranium is found mainly in roll-front type deposits in the Gulf Coast Uranium Province in Eocene to Pliocene clastic rocks (Fig. 2). These sediments were deposited in two fluvial systems, the Gueydan system of the Rio Grande embayment in southern Texas and the Chita-Corrigan system in the Houston embayment in eastern Texas. The two systems interfinger at the San Marcos arch (Fig. 3) (Galloway et al. 1979).

\section{Deposit Characteristics}

Deposits are found in carbonaceous facies of the host formations or associated with faulting that may transport gases produced from underlying hydrocarbons into the host rocks. Both settings provide the reducing conditions that favor uranium precipitation from groundwater. Uranium ore bodies in south Texas typically deposit in a C-shaped roll, with individual variations controlled by local variations in sand facies and the location of reductants. Individual ore bodies are fairly small, usually less than $5 \mathrm{~m}$ thick and poddy. Ore bodies are discontinuous over several kilometers and stacked with "ghost rolls" found behind the relatively young and actively migrating mineralized fronts (Adams and Smith 1981; International Atomic Energy Agency 2009). Deposits range from about 70,000 to close to 


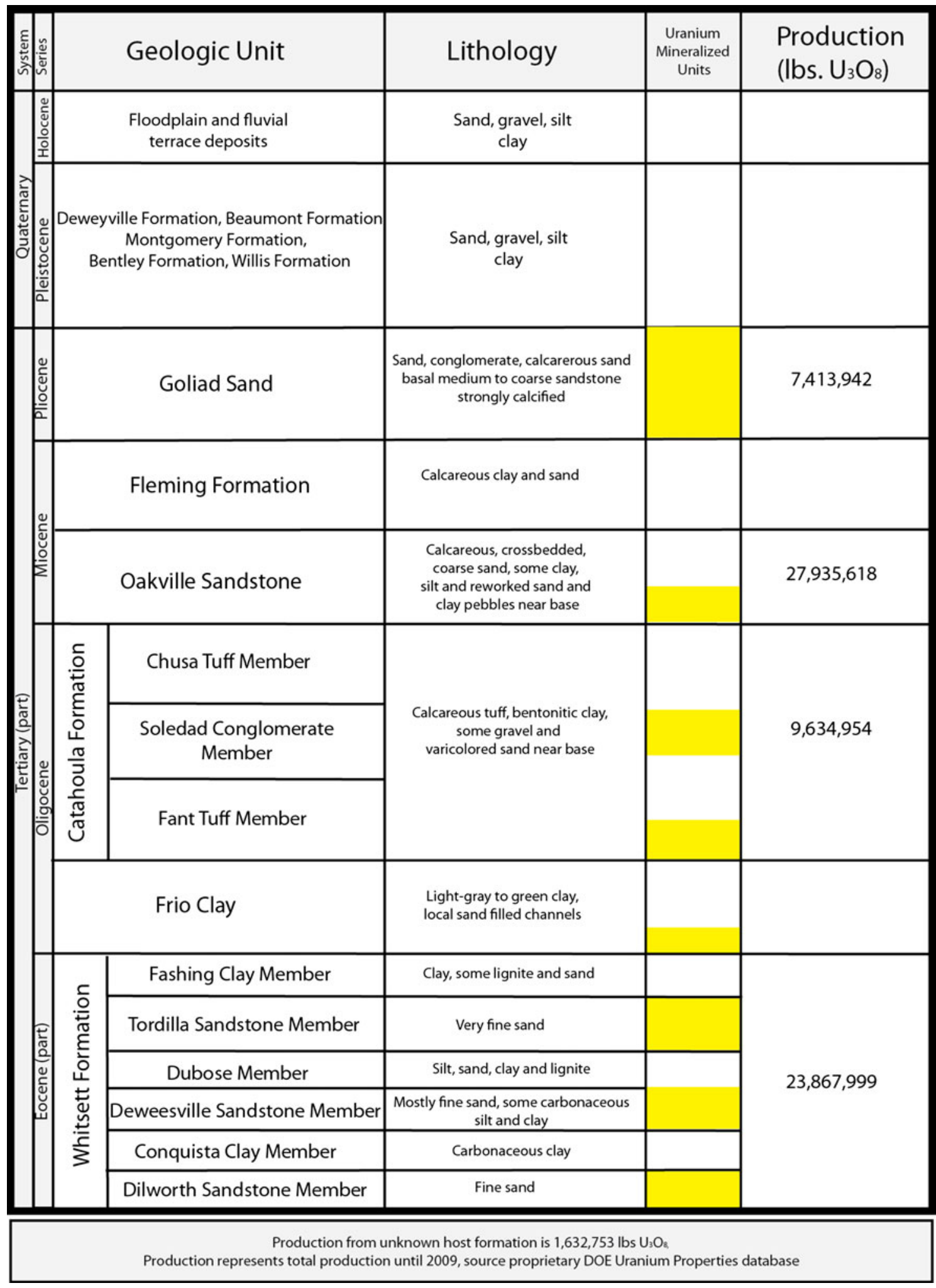

Figure 2. Tertiary units known to contain uranium mineralization (yellow highlights) in the Gulf Coast Uranium Province (after Galloway et al. 1979). 


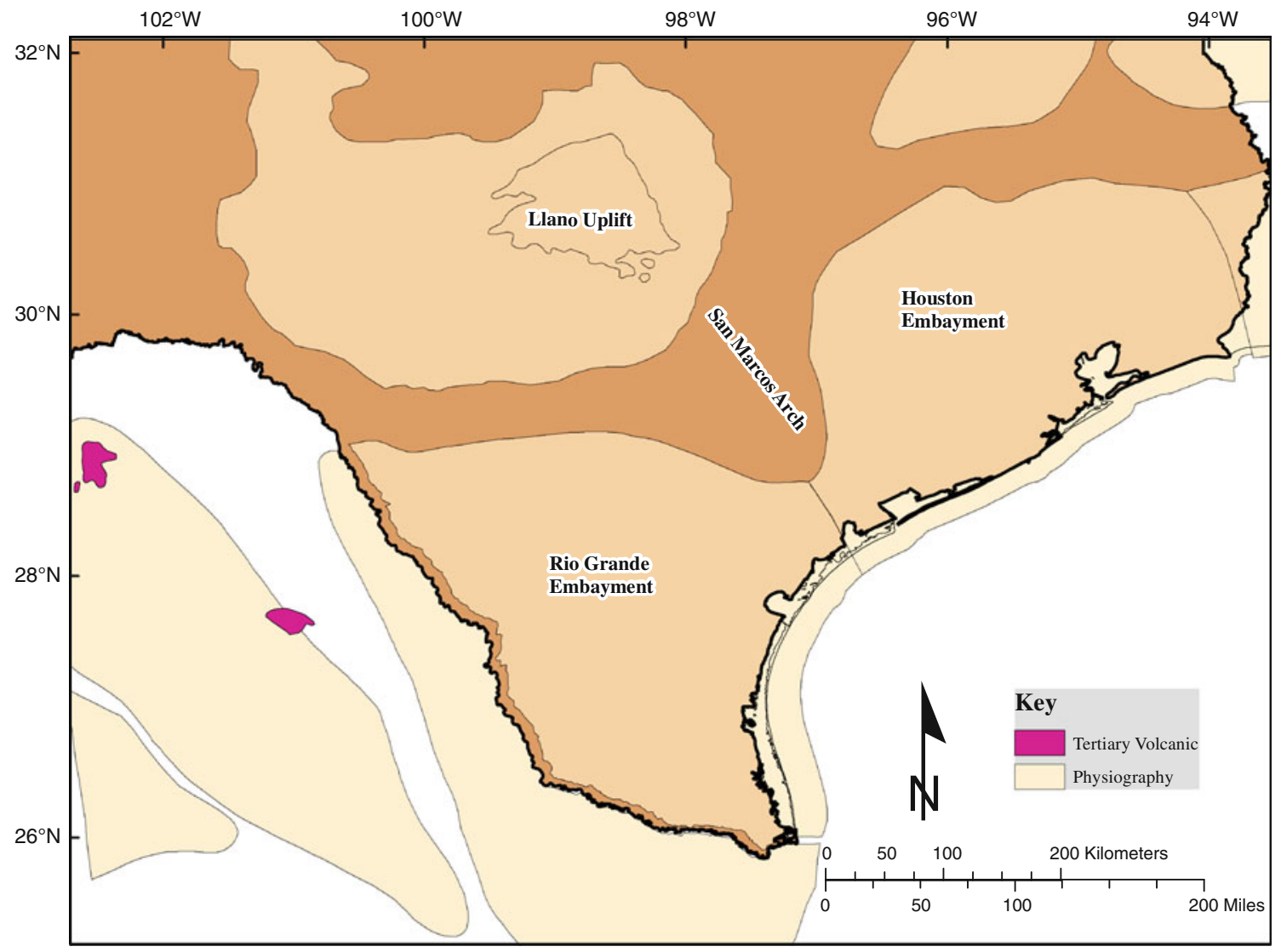

Figure 3. Location of major physiographic regions in the Gulf Coast Uranium Province.

10 million pounds of $\mathrm{U}_{3} \mathrm{O}_{8}$ in total size and average $0.09-0.10 \% \quad \mathrm{U}_{3} \mathrm{O}_{8}$ (International Atomic Energy Agency 2009; Dahlkamp 2010).

\section{Deposit Model}

The deposit model, developed by Adams and Smith (1981) and described below, has not changed significantly since the province was assessed during the NURE program. Exploration for deposits is still guided by these proposed source, transport, and trapping mechanisms.

\section{Uranium Source}

The source of uranium in Gulf-coast roll front deposits is poorly understood, but is thought to be tuffs interbedded with host sandstones derived from Tertiary volcanic centers in NE Mexico and volcanic rock fragments within sedimentary rocks sourced from southwest highland areas (Fig. 3) (Adams and Smith 1981; Eargle et al. 1975). The San Marcos arch may have controlled the easternmost distribution of these weathered sedimentary rocks and the volcanic ash effectively limiting the supply of labile uranium to west of this paleo-high (Baker 1979).

\section{Uranium Transport}

Groundwater leached uranium from source rocks, moving it down gradient through the sandstones with the highest transmissivity as reduction/ oxidation reaction fronts (Galloway et al. 1979). During the Tertiary, west Texas was characterized by an arid to semi-arid environment (Galloway 1977; Galloway and Kaiser 1979). This environment was more favorable to the formation of economic uranium deposits than the more humid paleoenvironment in east Texas (Adams and Smith 1981; Eargle et al. 1975). A number of reasons for this association 
of arid environments with the formation of roll-front deposits have been advanced.

\section{Uranium Trapping Mechanisms}

The predominant control of uranium deposition in the Gulf Coast Uranium Province appears to be reducing conditions caused by methane or hydrogen sulfide gas that has moved up deep-seated structures, or along the edges of structural highs such as salt domes, from oil and gas fields that underlie the Tertiary section (Adams and Smith 1981; Arredondo 1991; Carothers 2008, 2010; Classen 1981; Goldhaber et al. 1978). However, some south Texas deposits formed in response to reduction related to lignite and other organic matter in the local sandstones (Reynolds et al. 1982). In places, deposits are richest where very permeable channel sandstones interfinger with muddy organic-rich overbank deposits along

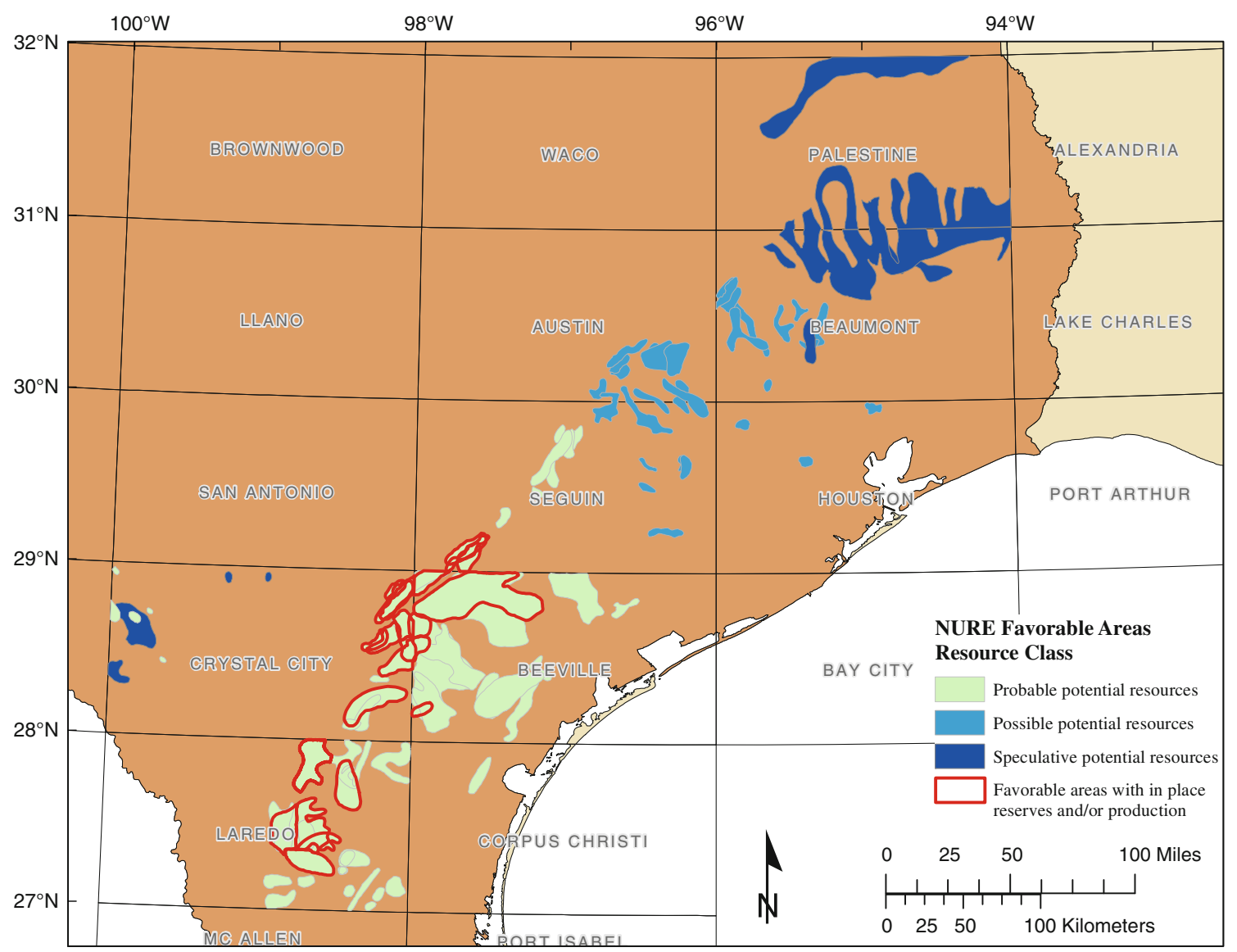

Figure 4. NURE favorable areas in the Gulf Coast Uranium Province. Not all favorable areas identified by the NURE program could be located.

Table 1. NURE Endowment, in Pounds of Uranium Oxide, for the Gulf Coast Uranium Province Portion of the Coastal Plain Resource Region

\begin{tabular}{|c|c|c|c|c|}
\hline $\begin{array}{l}\text { Potential } \\
\text { Resource }\end{array}$ & $\begin{array}{l}\text { Conditional } \\
\text { Endowment } \\
\left(\mathrm{lb} \mathrm{U}_{3} \mathrm{O}_{8}\right)\end{array}$ & $\begin{array}{l}\text { Unconditional } \\
\text { Endowment } \\
\left(\mathrm{lb} \mathrm{U}_{3} \mathrm{O}_{8}\right)\end{array}$ & $\begin{array}{l}\text { Conditional Endowment Cost } \\
\text { Category } \$ 30 / l b \mathrm{U}_{3} \mathrm{O}_{8} \\
\left(\mathrm{lb} \mathrm{U}_{3} \mathrm{O}_{8}\right)\end{array}$ & $\begin{array}{l}\text { Unconditional Endowment } \\
\text { Cost Category } \$ 30 / 1 b \mathrm{U}_{3} \mathrm{O}_{8} \\
\qquad\left(\mathrm{lb} \mathrm{U}_{3} \mathrm{O}_{8}\right)\end{array}$ \\
\hline Probable & $950,340,400$ & $924,289,200$ & $443,124,368$ & $431,870,813$ \\
\hline Possible & $497,612,600$ & $414,948,400$ & $190,527,835$ & $163,541,266$ \\
\hline Speculative & $39,087,800$ & $30,750,800$ & $9,048,433$ & $7,149,288$ \\
\hline Total Endowment & $1,487,040,800$ & $1,369,988,400$ & $642,700,636$ & $602,561,367$ \\
\hline
\end{tabular}


the flanks of the channels. This distribution may be related to fluid flow, the concentration of organic matter in overbank deposits or both.

\section{NURE COASTAL PLAIN RESOURCE REGION ASSESSMENT}

The Gulf Coast Uranium Province was part of NURE's Coastal Plain Resource Region that

Table 2. Production from Mines in the Gulf Coast Uranium Province

\begin{tabular}{lc}
\hline Host Formation & Total Production $\left(\mathrm{lb} \mathrm{U}_{3} \mathrm{O}_{8}\right)$ \\
\hline Whitsett Formation & $23,867,999$ \\
Catahoula Formation & $9,634,954$ \\
Oakville Sandstone & $27,935,618$ \\
Goliad Sand & $7,413,942$ \\
Unknown host formation & $1,632,753$ \\
Total Production & $70,485,266$ \\
\hline
\end{tabular}

Production data from U.S. Department of Energy (2009). extends along the Gulf and Atlantic coasts from southwestern Texas to New Jersey (Fig. 1). To determine if portions of the province were favorable for the formation of uranium deposits, geochemical and geophysical data were combined with geologic analysis by the NURE assessment team. Gamma-ray surveys of oil and gas drill holes were used to identify mineralized areas in the Beeville, Laredo, and Austin quadrangles (U.S. Department of Energy 1980). Regional aerial radiometric surveys were useful in identifying outcropping mineralization and positioning faults commonly associated with mineralization in the region (U.S. Department of Energy 1980). Geochemical analysis of streamsediment and ground-water samples was also used to define permissive areas in the Tertiary Whitsett and Catahoula Formations, Oakville Sandstone and Goliad Sand (Fig. 2). Minor potential resources were identified in other Tertiary units including the Oligocene Dilworth Sandstone Member of the Whitsett Formation and other units stratigraphically

Table 3. Uranium Production Data from NURE Favorable Areas

\begin{tabular}{|c|c|c|c|c|}
\hline $\begin{array}{l}\text { NURE } \\
\text { Favorable Area }\end{array}$ & $\begin{array}{c}\text { 1:250,000 Quadrangle } \\
\text { Name }\end{array}$ & $\begin{array}{l}\text { Production and Reserves } \\
\text { by Locality }\left(\mathrm{lb}_{3} \mathrm{O}_{8}\right)^{\mathrm{a}}\end{array}$ & $\begin{array}{c}\text { NURE Conditional } \\
\text { Endowment }^{\mathrm{b}}\left(\mathrm{lb} \mathrm{U}_{3} \mathrm{O}_{8}\right)\end{array}$ & $\begin{array}{c}\text { NURE Unconditional } \\
\text { Endowment at } \$ 30 / \mathrm{lb}^{\mathrm{c}}\left(\mathrm{lb}_{3} \mathrm{O}_{8}\right)\end{array}$ \\
\hline 14010011 & Beeville & $6,900,000$ & $29,660,000$ & $11,932,218$ \\
\hline 14010032 & Beeville & $1,504,970$ & $2,600,000$ & 969,540 \\
\hline 14010038 & Beeville & $1,980,000$ & $6,152,000$ & $3,099,378$ \\
\hline 14011045 & Beeville & $5,990,903$ & $34,760,000$ & $15,767,136$ \\
\hline 14010030 & Crystal City & $19,052,784$ & $53,600,000$ & $30,117,840$ \\
\hline 14010034 & Crystal City & $8,585,950$ & $32,360,000$ & $18,419,312$ \\
\hline 14010035 & Crystal City & 901,520 & $8,112,000$ & $4,543,531$ \\
\hline 14010040 & Crystal City & $2,360,640$ & $9,848,000$ & $5,218,455$ \\
\hline 14011036 & Crystal City & $1,355,213$ & $2,584,000$ & $1,301,819$ \\
\hline 14011037 & Crystal City & 691,508 & $8,092,000$ & $4,134,203$ \\
\hline 14011041 & Crystal City & $6,663,695$ & $5,704,000$ & $3,059,626$ \\
\hline 14011042 & Crystal City & $7,350,775$ & $2,568,000$ & $1,392,626$ \\
\hline 14011043 & Crystal City & $4,607,447$ & 524,400 & 311,494 \\
\hline 14020021 & Laredo & $7,372,118$ & $86,000,000$ & $38,949,400$ \\
\hline 14020022 & Laredo & 567,505 & $68,900,000$ & $32,865,300$ \\
\hline 14020026 & Laredo & $2,450,000$ & $65,040,000$ & $30,107,016$ \\
\hline 14020080 & Laredo & 477,166 & $11,222,000$ & $5,572,845$ \\
\hline 14021024 & Laredo & $9,956,618$ & $38,380,000$ & $12,757,512$ \\
\hline 14030011 & Laredo & 100,000 & $77,900,000$ & $38,763,040$ \\
\hline 14011046 & Seguin & $1,352,810$ & $3,820,000$ & $2,056,688$ \\
\hline 14011047 & Seguin & $1,200,000$ & $4,998,000$ & $2,672,930$ \\
\hline 14011048 & Seguin & $1,233,216$ & $4,014,000$ & $2,072,027$ \\
\hline \multicolumn{2}{|c|}{$\begin{array}{l}\text { Production from mines not located within } \\
\text { a known NURE favorable area }\end{array}$} & $15,185,162$ & & \\
\hline \multicolumn{2}{|c|}{ Tailings Production } & 173,215 & & \\
\hline \multicolumn{2}{|c|}{ Total } & $108,013,215$ & $556,838,400$ & $266,083,936$ \\
\hline
\end{tabular}

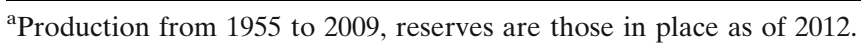

${ }^{\mathrm{b}}$ Unconditional potential endowment is the same as conditional endowment for these favorable areas.

${ }^{\mathrm{c}}$ The $\$ 30 / \mathrm{lb}$ uranium cost category was calculated in 1980 at current prices. Inflation would place this at approximately $\$ 85 / \mathrm{lb}$ in 2012 prices (U.S. Department of Labor 2012). 
below the Whitsett Formation including the Oligocene Manning Clay, Eocene Yegua Formation and Eocene Wilcox Formation. A DOE drilling project in the region tested for mineralization in the Oakville Sandstone and Goliad Sand. The 12 holes drilled in this area resulted in a reduction in area originally thought favorable for mineralization (U.S. Department of Energy 1980).

A series of subject quadrangle reports was prepared for the quadrangles assessed in Texas, the Austin, Beaumont, Beeville, Brownsville, Corpus Christi, Crystal City, Houston, Laredo, McAllen, Palestine, San Antonio, and Seguin quadrangles, and are published as the Department of Energy PGJ/F publication series. These reports describe the geologic setting, geochemistry, and geophysics of rock units in the quadrangles. This information was then combined to select areas that are favorable to host uranium deposits. Maps that accompany the reports show the location of uranium occurrences, water and stream sediment samples and their composition, formation thickness maps, structure contour maps to formation tops, total sandstone thickness maps, sandstone to shale ratio maps, land and culture maps and cross sections. Each subject quadrangle report contains a plate showing polygons considered favorable for the occurrence of uranium deposits. These polygons were defined by the assessment team following analysis of the geologic, geochemical, and geophysical data.

Near the end of the NURE program, the geology division of the data integration group within the BENDIX Field Engineering Corporation (DOE contractor) produced a series of reports summarizing NURE resource assessments. This was the 1980 Uranium Resource Summary Series, and included a volume for each resource region including the Coastal Plain regions that is the focus of this analysis (Bendix 1980). These reports contained assessment parameters organized by 1:250,000 quadrangles and a map of the polygons assessed during this phase of the NURE program. This series is available as a microfiche appendix to the final DOE NURE report (U.S. Department of Energy 1980). These reports include conditional and unconditional (see below) potential uranium resources estimates for the individual assessment localities. Also reported are cost factors used in the economic analysis that was applied to the estimated potential resource to calculate resources in the $\$ 30, \$ 50$, and $\$ 100$ per pound cost categories. For each favorable area the depth to mineralization is estimated as well as the size of the favorable area, thickness of geologic unit, average grade, and density of mineralization. USGS has a complete copy of final reports for all the resource areas assessed by NURE, and has extracted key data from the favorable area reports into spreadsheets to use in analyzing NURE assessments.

There is a great deal of uncertainty in determining the location of polygons identified on quadrangle maps with favorable area reports tabulating resources within these polygons. The numbering system used in maps that accompany the favorable area reports cannot be used to correlate the polygons with corresponding estimated resources (U.S. Department of Energy 1980). Adding further confusion, maps showing the location of favorable areas found in the NURE subject quadrangle reports do not match those found in the summary resource assessment reports. Although the polygons are typically in the same general location, for instance the southeast corner of the map, the outlines of the polygons and the number of polygons varies significantly. Why these two products of the NURE program are not consistent is unknown. The area of the polygons identified in the BENDIX data integration group reports was used to correlate the polygons with the assessment reports. Using this method many, but not all, of the favorable areas could be located in those areas assessed by 1980 . The location of favorable areas assessed after 1980, including those in the San Antonio and McAllen quadrangles, is unknown because no maps accompanied the assessment reports. In all, 74 of the 106 favorable areas were georeferenced for the region (Fig. 4).

\section{NURE ASSESSMENT METHODOLOGY}

The NURE assessment estimated conditional and unconditional potential resources for the favorable areas in the Gulf Coast Uranium Province (Appendix). Uranium endowment is estimated as summarized below, and is more completely described in the final U.S. uranium assessment report by DOE (U.S. Department of Energy 1980), in USGS Circular 994 (Finch and McCammon 1987) and in International Atomic Energy Agency Technical Document 344 (International Atomic Energy Agency 1992). Note that contrary to more common usage of endowment as including both reserves and undiscovered resources, in the NURE assessment methodology endowment refers to undiscovered resources only, and does not include reserves, which are considered separately: 


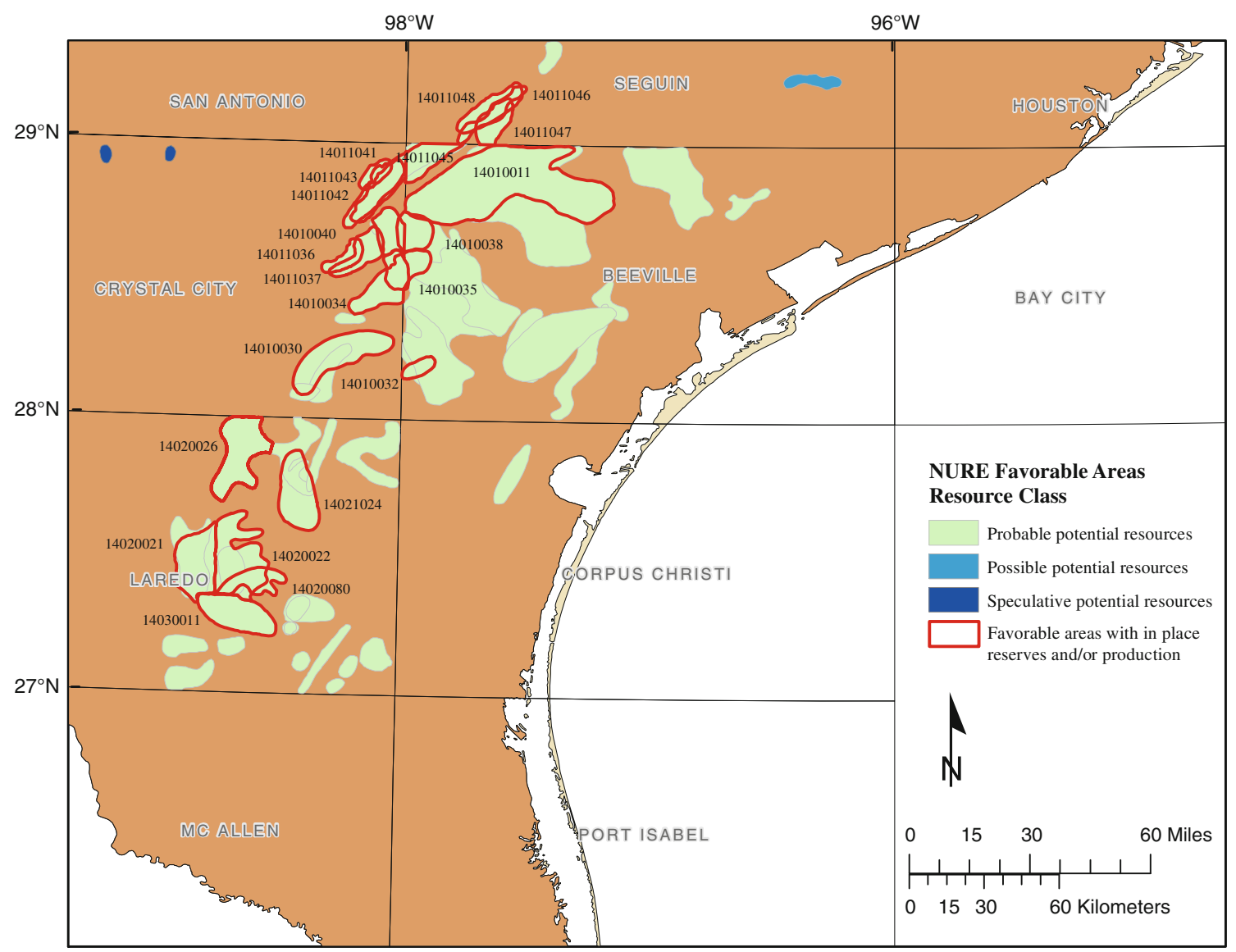

Figure 5. Areas favorable for uranium endowment identified during NURE that contain in place reserves or have produced uranium.

\section{Conditional Uranium Endowment (tons $\mathrm{U}_{3} \mathrm{O}_{8}$ )}

$$
=A \times F \times T \times G
$$

where $A=$ projected surface area of favorable ground in square miles, $F=$ fraction of $A$ that is underlain by endowment, $T=$ tons of endowed rock per square mile (thickness of mineralized unit $\times$ rock density), $G=$ average grade of endowment (three grades were estimated: high/modal/low).

Unconditional endowment is estimated by applying a probability, elicited by the principal investigator from the resource appraisal group, that one or more deposits exist within the favorable area. The probability ranges from 1 (a $100 \%$ probability that one deposit will be found) to 0 (a $0 \%$ probability that one deposit will be found). Therefore, if an investigator is highly confident that at least one deposit will be discovered in a favorable areas, the unconditional and conditional endowments will be the same. With a decreased level of confidence on the part of the investigator, unconditional endowment will be less than conditional endowment. Conditional and unconditional potential resources are estimated at the mean, the 95th, 75th, 50th, 25th, and 5th percentiles. The mean endowment was selected for this analysis.

During NURE, economic filters were added to endowment to determine reserves and potential resources in the $\$ 30, \$ 50$, and $\$ 100$ per pound cost categories (1980 prices). In the subsequent analysis, resources in the $\$ 30$ per pound cost category were considered. This corresponds to approximately $\$ 85 /$ lb in 2012 prices (U.S. Department of Labor 2012). Uranium prices have varied considerably, trending downward from 1980 and reaching a low in 1994 of about $\$ 7 / 1 b \quad \mathrm{U}_{3} \mathrm{O}_{8}$. Prices then began to rebound until achieving a high of $\$ 136 / 1 b \mathrm{U}_{3} \mathrm{O}_{8}$ in 2007. In 2012 uranium prices have averaged about $\$ 50 / \mathrm{lb}$ $\mathrm{U}_{3} \mathrm{O}_{8}$ (Organisation of Economic Cooperation and Development Nuclear Energy Agency and 
International Atomic Energy Agency 1996, 2012). Examination of uranium price trends indicates that the NURE $\$ 30 / 1 b \mathrm{U}_{3} \mathrm{O}_{8}$ uranium price category is the most appropriate to use in an analysis of uranium production between 1980 and 2012 .

Potential resources were also categorized as probable, possible, and speculative. Probable potential resources are in known districts as extensions of known deposits or new deposits within trends or mineralized areas that have been identified by exploration. Possible potential resources are found in formations or geologic settings that are productive elsewhere, but in which a deposit has not yet been identified within the considered favorable area. Speculative potential resources are located in formations or geologic settings that have not previously been productive but are within a productive province and share characteristics with the productive areas. The details of this analysis were stored in the Uranium Reserves and Data, URAD, database (Das and Lee 1991). Despite ongoing work to try to find this database by USGS and EIA, it has not been located therefore cannot be recreated or analyzed. Detailed descriptions of the NURE assessment methodology are found in Finch and McCammon (1987) and U.S. Department of Energy (1980).

\section{URANIUM ENDOWMENT OF THE GULF COAST URANIUM PROVINCE}

In the Gulf Coast Uranium Province, 106 favorable areas were defined in 11 1:250,000 scale quadrangle maps by the NURE program (Fig. 4). The conditional and unconditional potential uranium endowment was estimated for each of these areas (Appendix). NURE estimated a conditional endowment of about 1.5 billion pounds of $\mathrm{U}_{3} \mathrm{O}_{8}$, and an unconditional endowment of about 1.4 billion pounds of $\mathrm{U}_{3} \mathrm{O}_{8}$ in three potential resource classes in this province (Table 1; Appendix). Of this, about 643 million pounds of the conditional and 600 million pounds of the unconditional endowment are within the $\$ 30 / \mathrm{lb} \mathrm{U}_{3} \mathrm{O}_{8}$ cost category (Table 1 ). In addition, reserves of 86 million pounds of $\mathrm{U}_{3} \mathrm{O}_{8}$ were estimated for the entire NURE Coastal Plain Resource Region.

\section{ANALYSIS OF NURE ENDOWMENT}

Three decades of exploration and development provide information that can be used to place more practical limits on productive portions of the basin. Historic and current mining depths can be used to examine the depth limits considered during NURE. As well, favorable areas in regions where rigorous exploration has failed to identify reserves should be examined to determine whether continuing to include this endowment in the reported endowment of the region is appropriate. Updated reserve and production data can be used to examine whether or not reserves predicted for the region were accurate.

\section{Production and Reserves}

Uranium production has been ongoing in Texas since 1955 even through the interval of low uranium prices in the 1980s and 1990s. The DOE has tabulated cumulative uranium production in the United States, compiling a database of production and reserves which is the basis for this analysis of the uranium reserves and endowment calculated by NURE. In the current USGS study, DOE's reserve and production data were supplemented by information from the International Atomic Energy Agency world uranium deposits database (UDEPO), and NI 43-101 reports filed with Canadian securities administrators (International Atomic Energy Agency 2010; Carothers 2008, 2009, 2010). Deposits are those named in the DOE database, with no attempt at aggregation of smaller properties into larger deposit clusters. Deposits were located using a variety of resources including the original NURE geologic quadrangle reports, and exploration and production maps compiled by the Texas Commission on Environmental Quality and Texas Railroad Commission.

Between 1955 and 2009 approximately 70 million pounds of $\mathrm{U}_{3} \mathrm{O}_{8}$ were produced from 102 mines in the Gulf Coast Uranium Province (Table 2) (U.S. Department of Energy 2009). Thirty million pounds of $\mathrm{U}_{3} \mathrm{O}_{8}$ was mined prior to 1980, almost all from mines in Karnes County, Texas (U.S. Department of Energy 1980). Therefore, approximately 40 million pounds of $\mathrm{U}_{3} \mathrm{O}_{8}$ in production post-dated NURE. The NURE program calculated reserves of 87 million pounds of $\mathrm{U}_{3} \mathrm{O}_{8}$ in the $\$ 30 / \mathrm{lb}$ cost category, for the entire Coastal Plain province, most, but not all, of which was in the Gulf Coast Uranium Province (U.S. Department of Energy 1980). Post-NURE production was a little less than half that predicted reserve. By examining the DOE uranium mines and production database and adding information from 
other sources, the current USGS study tabulated 38 million pounds of $\mathrm{U}_{3} \mathrm{O}_{8}$ of in place reserves identified for the province as of 2012.

Twenty-two of the 106 favorable areas in the Gulf Coast Uranium Province that we have been able to georeference report production or contain reserves (Table 3; Fig. 5). The potential endowment calculated by NURE for these favorable areas is included to illustrate their relative importance; however, reserves calculated by NURE cannot be reported by favorable area because this information has been lost. Five properties containing in all over 15 million pounds of $\mathrm{U}_{3} \mathrm{O}_{8}$ in total endowment are located outside the area of any of the known NURE favorable areas. Eight million pounds of produced $\mathrm{U}_{3} \mathrm{O}_{8}$ are estimated for properties that could not be located but are included in DOE database. The production from these properties was not considered in this analysis. A small amount of production is assigned to reprocessing of tailings, and is not considered here (Table 3).

\section{DISCUSSION}

In all, 108 million pounds of $\mathrm{U}_{3} \mathrm{O}_{8}$ in production or reserves were calculated for the Gulf Coast Uranium Province by the current study. Reserves in the $\$ 30 / \mathrm{lb}$ cost category calculated by the NURE program for the entire Coastal Plain Region plus past production which was almost all from mines in the Gulf Coast Province were 117 million pounds of $\mathrm{U}_{3} \mathrm{O}_{8}$. The close correlation of total reserves plus production for this area as calculated by NURE and the current study indicates that the methodology used to calculated reserves during NURE appears to have been sound in predicting the identification of economic uranium deposits in the region. Considering the complexities of developing uranium mines and fluctuating, but low average price during the 30 years since the end of NURE, production (40 million pounds of $\mathrm{U}_{3} \mathrm{O}_{8}$ ) of approximately half the reserves predicted by the program $(87$ million pounds of $\mathrm{U}_{3} \mathrm{O}_{8}$ ) is reasonable.

All but two mines, the Kingsville Dome and Alta Mesa mines fall within a known NURE favorable area in south Texas. These two mines are within a quadrangle parts of which were assessed after 1980 and for which we do not have the location of favorable areas, therefore they may actually be included in areas that are not now locatable. The high correlation between production and favorable areas indicates the NURE program accurately predicted prospective ground.

In addition to reserves, between 600 and 640 million pounds of potential resources in the $\$ 30 / \mathrm{lb}$ cost category were identified during NURE (Appendix). This analysis indicates that little of these potential resources has been produced or further delineated into reserves. Of the 106 favorable areas identified by NURE, only 22 produced uranium or contain in place reserves. This indicates that the number of favorable areas and their estimated potential resources as predicted by NURE may have been much higher than those reserves that are actually economically and technically recoverable.

A number of factors may have influenced the lack of production from the potential resources estimated for the region. One factor is the high cost category of $\$ 30 / 1 b$ that was used as a minimum for the NURE estimates. Uranium prices have been below this threshold for most of the past 30 years, with the exception of the price spike in 2007. So it is understandable that little of the potential resource estimated economic at the $\$ 30 / 1 \mathrm{~b}$ threshold has been identified or mined. A $\$ 15 / \mathrm{lb}$ cost category was used early in the NURE program, but this information has been lost. A related factor is that uranium prices also drive exploration activity, and with the relatively low prices that have prevailed since 1980 uranium exploration activities have been relatively modest. Exploration expenditures usually closely correlate with the development of uranium resources (Organisation for Economic Cooperation and Development Nuclear Energy Agency and International Atomic Energy Agency 2010). This depressed level of exploration may explain the lack of discoveries. Another factor that may contribute to a lack of identified reserves is the high percentage of private land in Texas. Most of the uranium resources in Texas are located on private land to which access may be limited. In these scenarios, considerable resources may still remain to be discovered or fully defined as in place reserves in the region.

Other factors that may have influenced the lack of production from potential resources for the region may be inherent in the estimation methodology. The NURE minimum grade cutoff of $0.01 \%$ $\mathrm{U}_{3} \mathrm{O}_{8}$ used to calculate potential resources may have been too low a threshold such that it does not represent a realistic economic cutoff for mineable uranium deposits. This may have resulted in identification of a considerable resource in the region that is sub-economic. Also, as part of the NURE elici- 
tation process the assessor considers the distribution of deposits from well understood control deposit areas. If this comparison is imperfect, the resulting estimated resource will be inaccurate. The underlying goal of the NURE program was to help guide exploration in the region. Early in the assessment program for the Gulf Coast, managers expressed a desire to provide the nuclear industry with possible target areas for uranium exploration (Olsen and Parker 1975). The emphasis guided analysis of the Gulf Coast to include areas that contained some favorable, but not all critical, attributes to support the NURE potential resource estimates. This emphasis at the outset of the program may have resulted in inclusion of more marginally favorable areas into the potential resource class, particularly those defined in the speculative potential resource category. As the program progressed, the speculative potential resource category diminished in importance, as some later compilations exclude this class of resource.

\section{DISTRIBUTION OF POTENTIAL RESOURCES}

\section{Potential Resources in Non-productive Regions}

Although exploration was slowed by low uranium prices, industry sources describe regional exploration programs that targeted all portions of the Gulf Coast Uranium Province, even the less prospective Houston embayment. Currently the UEC Corporation has an exploration project in the Houston embayment, the Carrizo project in Zavala County, Texas (Ux Consulting 2010). However, despite these efforts, no commercial deposits have been developed in the Houston embayment.

Southwest of the San Marcos arch in the Rio Grande embayment the NURE program estimated the potential endowment to be 1.3 billion pounds of $\mathrm{U}_{3} \mathrm{O}_{8}$ in the conditional, 1.2 billion pounds of $\mathrm{U}_{3} \mathrm{O}_{8}$ in the unconditional, and 530 million of $\mathrm{U}_{3} \mathrm{O}_{8}$ in the $\$ 30 / \mathrm{lb}$ cost categories. East of the San Marcos arch in the Houston embayment, 27 favorable areas contain 232 million pounds of $\mathrm{U}_{3} \mathrm{O}_{8}$ of conditional, and 176 million pounds of $\mathrm{U}_{3} \mathrm{O}_{8}$ in the unconditional endowment category and 72 million pounds in the unconditional \$30/lb $\mathrm{U}_{3} \mathrm{O}_{8}$ cost category. The Houston embayment contains $16 \%$ of the conditional and $12 \%$ of the unconditional endowment of the Gulf Coast Uranium Province in any cost category, and $11 \%$ of the unconditional endowment in the $\$ 30 / \mathrm{lb}$ cost category.

In the Rio Grande embayment, $95 \%$ of the conditional endowment was considered unconditional, and in the Houston embayment only $76 \%$ of conditional endowment was moved into the unconditional category. Of the 79 areas in the Rio Grande embayment, the resources in 46 were considered in the probable, 25 in the possible and 8 in the speculative potential resource categories. In the Houston embayment, of 27 areas three were classified probable and the rest possible. Both the lower percentage of potential resources and the few areas classified as probable indicate the lack of confidence assessors had that a deposit would be identified in favorable areas in the Houston embayment.

Many factors may contribute to the lack of uranium resources in the Houston embayment. Two aspects are the abundance of volcanic detritus that provided uranium and the pervasive reducing conditions in the Tertiary units likely to be host rocks. Volcanic tuffs, volcaniclastics, and other weathered sedimentary rocks thought to be the uranium source in the province derive from highland areas west of the region. At the San Marcos arch, and northeastward, the tuff content of the Oligocene Catahoula Formation drops markedly (Baker 1979). NURE assigned resources to increasingly more hypothetical resource classes the further the favorable areas were from the uranium source (Fig. 4). Although no narrative has been found that accompanies the NURE favorable area reports, the author speculates that assessors may have set this ranking to reflect the lack of source rocks in the northeastern portion of the province.

The arid to semi-arid conditions that favor weathering and transport of uranium in groundwater may not have developed in the more humid environment of the Houston embayment. In addition, a humid environment supports higher terrestrial biologic productivity, and as a result more abundant organic matter within a depositional sequence. In such an environment, uranium is expected to be retained in the broadly distributed organic-rich facies that are found throughout the Houston embayment. The resulting dissemination of organic matter throughout the stratigraphic section would sequester uranium within organics rather than allow the steep gradients needed to create an economic deposit. 
Table 4. Percentage of the NURE Conditional and Unconditional Endowment Distribution by Depth in the Rio Grande and Houston Embayments

\begin{tabular}{|c|c|c|c|c|}
\hline \multirow[t]{2}{*}{ Depth (ft) } & \multicolumn{2}{|c|}{ Rio Grande Embayment } & \multicolumn{2}{|c|}{ Houston Embayment } \\
\hline & $\begin{array}{c}\text { Percent of Conditional } \\
\text { Endowment }\end{array}$ & $\begin{array}{c}\text { Percent of Unconditional } \\
\text { Endowment }\end{array}$ & $\begin{array}{l}\text { Percent of Conditional } \\
\text { Endowment }\end{array}$ & $\begin{array}{c}\text { Percent of Unconditional } \\
\text { Endowment }\end{array}$ \\
\hline$<50$ & 1 & $<1$ & 3 & 2 \\
\hline $50-150$ & 6 & 6 & 9 & 10 \\
\hline $150-250$ & 8 & 9 & 10 & 11 \\
\hline $250-350$ & 16 & 17 & 10 & 12 \\
\hline $350-450$ & 18 & 19 & 9 & 10 \\
\hline $450-750$ & 25 & 26 & 14 & 13 \\
\hline $750-1250$ & 10 & 9 & 13 & 11 \\
\hline $1250-1750$ & 5 & 5 & 17 & 16 \\
\hline $1750-2500$ & 7 & 7 & 15 & 15 \\
\hline $2500-3500$ & 3 & 2 & 0 & 0 \\
\hline $3500-4500$ & 1 & 0 & 0 & 0 \\
\hline
\end{tabular}

Table 5. NURE Estimated Endowment for the Western Gulf Coast Resource Region Reduced by Resources Estimated at Subeconomic Depths and that in Non-productive Portions of the Basin

\begin{tabular}{|c|c|c|c|}
\hline & $\begin{array}{l}\text { Conditional } \\
\text { Endowment } \\
\left(\mathrm{lb}_{3} \mathrm{O}_{8}\right)\end{array}$ & $\begin{array}{l}\text { Unconditional } \\
\text { Endowment } \\
\left(\mathrm{lb} \mathrm{U}_{3} \mathrm{O}_{8}\right)\end{array}$ & $\begin{array}{l}\text { Unconditional } \\
\text { Endowment in the } \$ 30 / 1 \mathrm{~b} \\
\text { Cost Category }\left(\mathrm{lb} \mathrm{U}_{3} \mathrm{O}_{8}\right)\end{array}$ \\
\hline $\begin{array}{l}\text { Endowment in the Texas } \\
\text { Gulf Coast }\end{array}$ & $1,487,040,800$ & $1,369,988,400$ & $602,561,368$ \\
\hline $\begin{array}{l}\text { Endowment in non-producing Houston } \\
\text { embayment }\end{array}$ & $232,928,600$ & $175,931,400$ & $72,208,664$ \\
\hline $\begin{array}{l}\text { Endowment below } 750 \mathrm{ft} \text { in the Rio Grande } \\
\text { embayment }\end{array}$ & $311,008,760$ & $264,711,308$ & $131,649,237$ \\
\hline $\begin{array}{l}\text { Total endowment with sub-economic } \\
\text { and non-producing regions removed }\end{array}$ & $943,103,440$ & $929,345,692$ & $398,703,467$ \\
\hline
\end{tabular}

\section{Potential Resource Distribution by Depth}

The NURE program reported percentages of conditional and unconditional resources by depth from the surface. Sandstones in this region were assessed up to a depth of $4500 \mathrm{ft}$, whereas most historic and modern mining in Texas ranges from the surface to $500 \mathrm{ft}$. Resources below $500 \mathrm{ft}$ may be difficult to economically recover in this region using technology that is currently available.

In the Rio Grande embayment, $26 \%$ of the conditional, and $23 \%$ of the unconditional endowment is assigned to depths greater than $750 \mathrm{ft}$ (Table 4). In the Houston embayment, $45 \%$ of the conditional and $42 \%$ of the unconditional endowment is assigned to depths greater than $750 \mathrm{ft}$.

Resources estimated to exist deeper than historic mining depths of about $500 \mathrm{ft}$ in the section have not historically been the target of exploitation by industry. Accordingly, including resources below depths that are subeconomic in the NURE assessment may be overly optimistic. To better represent the available endowment of the region, in this review, endowment below historically practicable mineable depths is removed from the regional endowment. For this analysis resources below $750 \mathrm{ft}$ were chosen as subeconomic based on known exploration and production data.

\section{Identification of Non-productive Areas of the Gulf Coast Uranium Province}

Removing endowment estimated below mining depths of $750 \mathrm{ft}$ that are currently subeconomic, and the endowment estimated for the Houston embayment, which has proved to be a non-productive region, the endowment for the Texas Gulf Coast is 
reduced to an endowment between 920 and 930 million pounds of $\mathrm{U}_{3} \mathrm{O}_{8}$ in the unrestricted cost categories, and to 399 million pounds in the $\$ 30 / \mathrm{lb}$ cost category. This is $37 \%$ less conditional, $32 \%$ less unconditional, and $34 \%$ less unconditional endowment in the $\$ 30 / 1 b$ cost category than originally estimated by the NURE program for this region (Table 5).

\section{CONCLUSIONS}

The NURE program completed a comprehensive assessment of uranium resources in the U.S. Gulf Coast Uranium Province. The uranium is likely sourced in volcanic ash and volcaniclastic rocks interbedded in clastic Tertiary sedimentary rocks in the province. Uranium is leached from volcanic rocks by alkaline groundwater, and then concentrated adjacent to unconsolidated sediments and gases that emanate from hydrocarbon accumnlations deeper in the section.

An undiscovered resource of between 1.4 and 1.5 billion pounds of $\mathrm{U}_{3} \mathrm{O}_{8}$ in 106 favorable areas was estimated for the province. Of this, between 600 and 640 million pounds of $\mathrm{U}_{3} \mathrm{O}_{8}$ was considered economic in the cost category of $\$ 30 / 1 b \mathrm{U}_{3} \mathrm{O}_{8}$. Just over $20 \%$ of the favorable areas delineated by the NURE program contain resources and production of a total 108 million pounds of $\mathrm{U}_{3} \mathrm{O}_{8} ; 70$ million pounds of production and 38 million pounds of in situ reserves. During NURE, 87 million pounds of reserves were identified in the Coastal Plain resource region, 40 million pounds of which were mined after the program ended. The remaining 47 million pounds remaining for the entire coastal plain region correlates well with the 38 million pounds calculated for this region by the current study. However, 600 million pounds of potential endowment in the $\$ 30 / 1 b$ cost category remains unmined. This analysis demonstrates that the NURE undiscovered resource program estimated a larger undiscovered resource base than has been practically economically recoverable in the ensuing 32 years. Some factors that may have influenced this include the low grade cutoff of $0.01 \% \mathrm{U}_{3} \mathrm{O}_{8}$ used in the NURE estimates and cost categories that are significantly higher than current or historic uranium prices. Using these cutoffs, much of the undiscovered resource is likely sub-economic. NURE was philosophically an exploration program focused on identifying potential resources. In this sense, NURE was a very effective program, as those reserves developed in the Gulf Coast Uranium Province are almost exclusively in favorable areas identified by the program. Other considerations are that low uranium prices that have typified the past 30 years may have discouraged the identification and exploitation of resources. In addition, the high percentage of potentially inaccessible private land in Texas can slow exploration because of the additional permissions necessary to explore in these areas.

The Houston embayment in the eastern portion of the province was ranked as a more speculative potential resource by the NURE assessment. This area has not proved productive and removal of resources assigned to the Houston embayment may be warranted. Although NURE assessed potential host rocks to $4500 \mathrm{ft}$ depth, mining to date has not exceeded $500 \mathrm{ft}$. To more accurately estimate technically recoverable resources, it may be necessary to exclude resources below this practicable mining depth. When resources in the non-productive Houston embayment and those below practicable mining depths in the rest of the basin are excluded, the undiscovered resource endowment of the province is reduced to between 930 and 940 million pounds of $\mathrm{U}_{3} \mathrm{O}_{8}$ in all cost categories, and 399 million pounds in the $\$ 30$ cost category.

This analysis could be applied to other uranium resource regions assessed by NURE to identify regions where the undiscovered resource endowment may be too high or too low. In some regions, uranium deposit models may have changed such that a reexamination of resources may be warranted. In other regions, significant exploration and production since NURE ended in 1980 may have identified uranium-rich areas not recognized during the last assessment, or condemned areas as non-productive.

\section{ACKNOWLEDGMENTS}

The NURE databases reconstruction has been spearheaded by George Breit, who has been aided greatly in his efforts by David Langford. Mark Hannon analyzed the digital data generated from NURE sheets, georeferenced the NURE polygons used in this report, and helped draft many of the figures. Reviews by George Breit and Jane Hammarstrom of USGS were invaluable. 


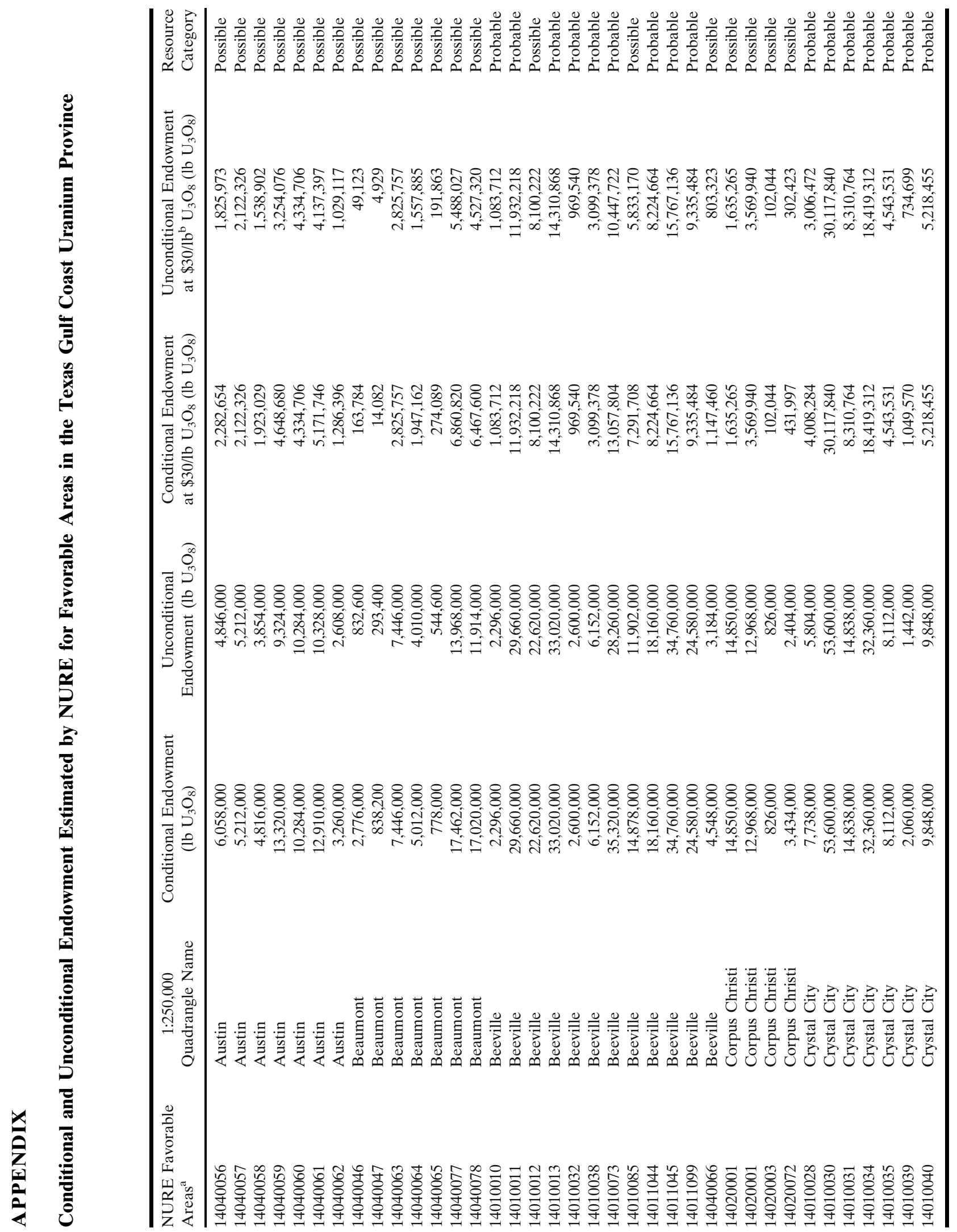




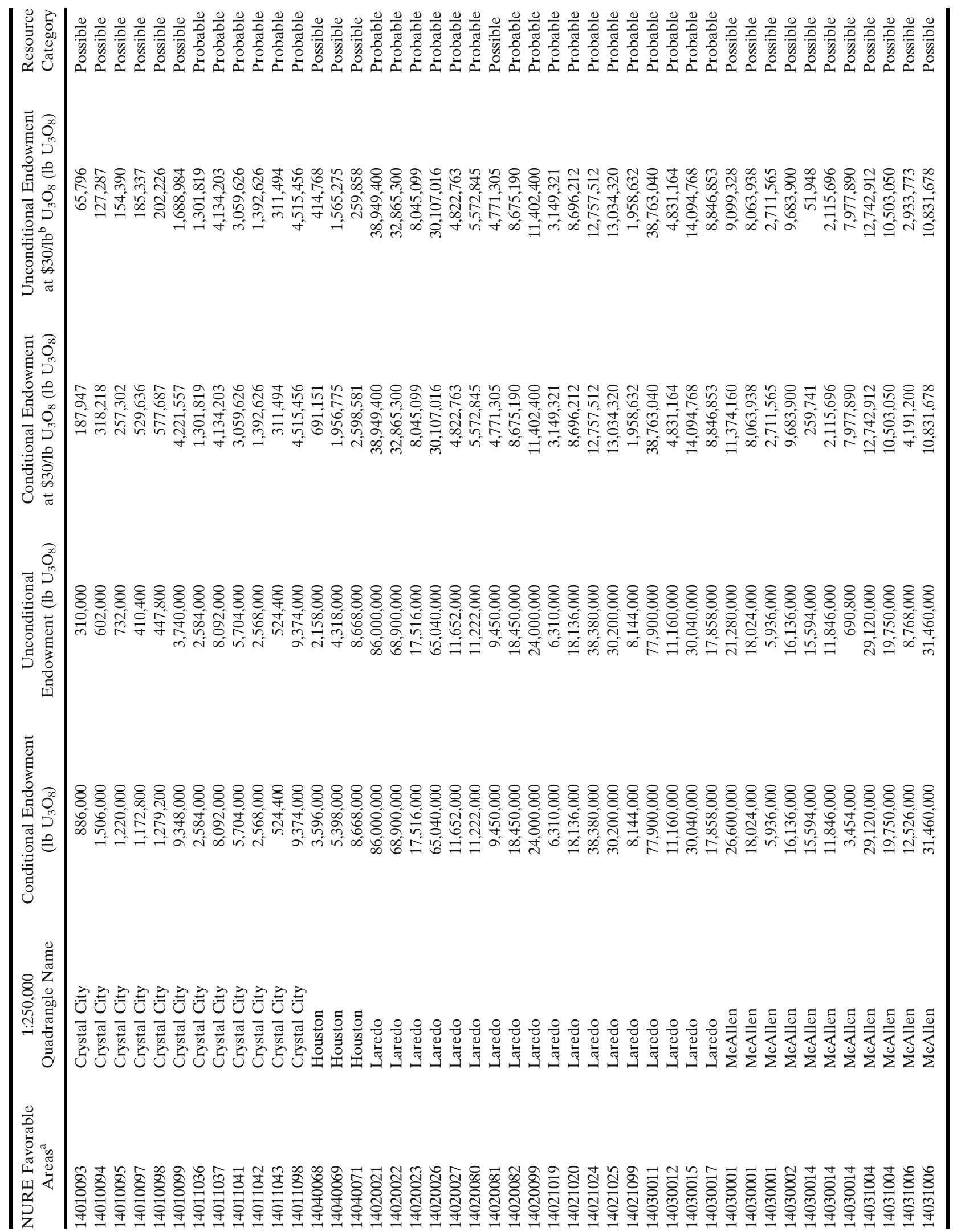




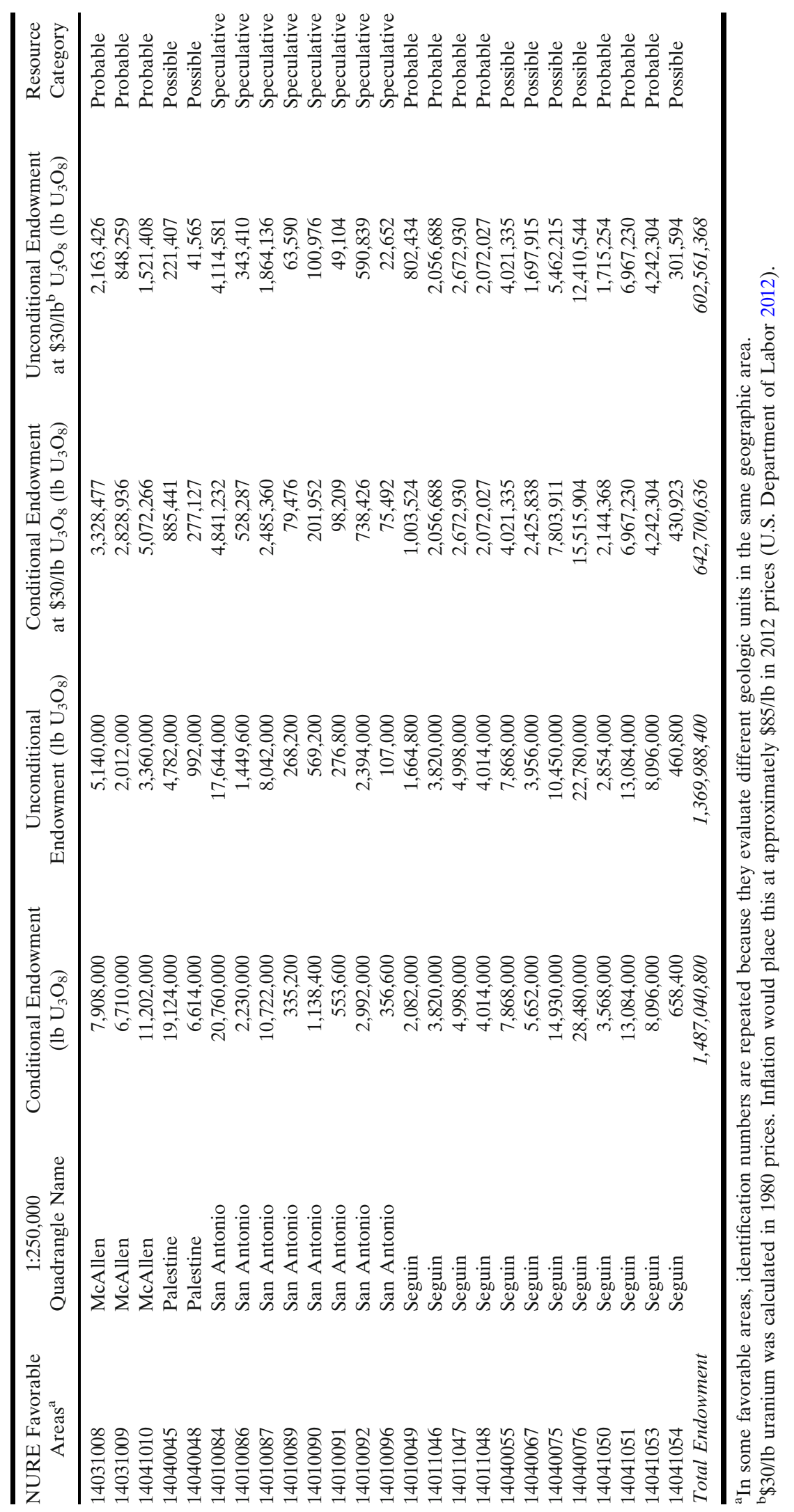




\section{Conversion Factors, Definitions, Abbreviations}

Conversion Factors

Inch/Pound to SI

\begin{tabular}{lll}
\hline Multiply & By & To Obtain \\
\hline Length & & \\
Foot (ft) & 0.3048 & Meter $(\mathrm{m})$ \\
Mile (mi) & 1.609 & Kilometer (km) \\
\hline
\end{tabular}

\section{Definitions}

Favorable area (U.S. Department of Energy 1980; International Atomic Agency 1992): “A geographic area in which the available data indicate the existence of geologic environments that are favorable for the concentration of uranium." Favorable areas exclude areas of mining or reserves.

Cost category: See potential resource below. Costs are calculated as forward costs per pound of $\mathrm{U}_{3} \mathrm{O}_{8}$. In the current study, $\$ 30 / 1 \mathrm{~b} \mathrm{U}_{3} \mathrm{O}_{8}$ was selected as the most appropriate economic cost category. Applying inflation, in 2012 dollars this economic cutoff would be approximately $\$ 85$, which is almost twice the current uranium price of about $\$ 50 / \mathrm{lb}$ $\mathrm{U}_{3} \mathrm{O}_{8}$ (U.S. Department of Labor 2012). This is below the average historic price for uranium since 1980 (Organisation for Economic Cooperation and Development Nuclear Energy Agency and International Atomic Energy Agency 2012). This simple inflationary treatment does not take into account variations in mining costs since 1981 because the original parameters used in NURE are no longer reproducible so cannot be analyzed.

Possible potential resource (Finch and McCammon 1987): Estimates of undiscovered or partly defined uranium deposits in rocks or geologic settings productive elsewhere within the same geologic province or subprovince.

Potential resource (Finch and McCammon 1987): The portion of the uranium endowment, in tons of $\mathrm{U}_{3} \mathrm{O}_{8}$, that are estimated to be producible at selected forward costs in dollars per pound of $\mathrm{U}_{3} \mathrm{O}_{8}$.

Probable potential resource (Finch and McCammon 1987): Estimates within known productive uranium areas that are either extensions of known deposits or undiscovered deposits within known geologic trends or areas of mineralization.
Speculative potential resource (Finch and McCammon 1987): Estimated quantities in undiscovered or partly defined deposits in formations or geologic settings not previously productive with a productive geologic province or subprovince or within a geologic province or subprovince not previously productive.

Technically recoverable resources: Those resources that are mineable using currently known methods of extraction without regard for cost.

Uranium assessment (Finch and McCammon 1987): The economic evaluation of undiscovered resources.

Undiscovered uranium resources: Uranium resources expected to exist based on the application of the geologic knowledge of known deposits to geologically similar regions.

Uranium deposit (modified from Finch and McCammon 1987): A discrete concentration of uranium mineralization that is of possible economic interest and/or is above a lower cutoff grade and of a minimal size. For this paper, deposits were defined by the U.S. Department of Energy Producing Uranium Mines database. No aggregation of smaller deposits was considered here because there was not good enough information about the location of each deposit listed in the DOE database.

Uranium endowment (U.S. Department of Energy 1980): Uranium endowment is an estimate of all uranium-bearing material having a grade of at least $0.01 \% \mathrm{U}_{3} \mathrm{O}_{8}$, postulated to occur in geologic settings favorable for undiscovered uranium deposits. The estimate is made previous to any consideration for the economics of exploration and exploitation, but it includes subsequent estimated potential resources, as well as associated additional material at or above the $0.01 \%$ cutoff grade within the area for which the estimate applies. Uranium endowment is the potential-related complement of the reserves-related uranium inventory.

Uranium reserves (U.S. Energy Information Administration 2012): Estimated quantities of uranium in known mineral deposits of such size, grade, and configuration that the uranium could be recovered at or below a specified production cost with currently proven mining and processing technology and under current law and regulations. Reserves are based on direct radiometric and chemical measurements of drill holes and other types of sampling of the deposits. Mineral grades and thickness, spatial relationships, depths below the surface, mining and reclamation methods, distances to milling facilities, and amenability of ores to processing are considered in the evaluation. The amount of uranium in ore that 
could be exploited within the chosen forward-cost levels are estimated in accordance with conventional engineering practices.

Uranium resources (Finch and McCammon 1987): A concentration of naturally occurring material in such form and amount that economic extraction is currently or potentially feasible.

\section{Abbreviations}

$\begin{array}{ll}\text { DOE } & \text { U.S. Department of Energy } \\ \text { NURE } & \begin{array}{l}\text { U.S. Department of Energy national } \\ \text { uranium resource evaluation program }\end{array} \\ \text { URAD } & \begin{array}{l}\text { U.S. Department of Energy "uranium } \\ \text { reserves and data" computer program } \\ \text { and database used to estimate potential } \\ \text { uranium resources }\end{array} \\ \text { USGS } & \text { U.S. Geological Survey }\end{array}$

\section{REFERENCES}

Adams, S. S., \& Smith, R. B. (1981). Geology and recognition criteria for sandstone uranium deposits in mixed fluvialshallow marine sedimentary sequences, South Texas, U.S. Department of Energy Report GJBX-4(81).

Arredondo, A. G. (1991). Geology and hydrogeology of the Kingsville Dome in situ leach uranium mine, Kleberg County, Texas. M.S. Thesis, Geology, Texas A \& I University, Kingsville, Texas.

Baker, E. T. (1979). Stratigraphic and hydrogeologic framework of part of the Coastal Plain of Texas, Texas Department of Water Resources, Report No. 236.

Bendix. (1980). 1980 NURE Uranium Resource Summaries-Coastal Plain, U.S. Department of Energy Grand Junction Office.

Carothers, T. A. (2008). Uranium Energy Corporation's Goliad project in situ recovery uranium property, Goliad County, Texas, 89 pp., NI 43-101 Technical Report. Accessed July 1, 2012, from www.sedar.com.

Carothers, T. A. (2009). Technical Report for Uranium Energy Corporation's Nichols Project, Karnes County, Texas, 44 pp., NI 43-101 Technical Report. Accessed July 1, 2012, from www.sedar.com.

Carothers, T. A. (2010). Technical report for Uranium Energy Corporations Salvo project, in situ recovery uranium property, Bee County, Texas, NI 43-101 Technical Report. Accessed July 1, 2012, from www.sedar.com.

Classen, D. R. (1981). Mineralogy and diagenesis of a uranium prospect in the Goliad Sandstone, Duval County, Texas. M.S. thesis, Geology, University of Missouri, Columbia, Missouri.

Dahlkamp, F. J. (2010). Uranium deposits of the world. Berlin: Springer.

Das, S., \& Lee, R. (1991). A computerized system to estimate potential uranium resources. Resources and Energy, 13, 201-215.

Eargle, D. H., Dickinson, K. A., \& Davis, B. O. (1975). South Texas uranium deposits. American Association of Petroleum Geologists Bulletin, 59, 766-779.
Finch, W. I. (1996). Uranium province of North America-Their definition, distribution and models. U.S. Geological Survey Circular, 2141..

Finch, W. I., \& McCammon, R. B. (1987). Uranium resource assessment by the Geological Survey: Methodology and plan to update the national resource base. U.S. Geological Survey Circular 994.

Galloway, W. E. (1977). Catahoula Formation of the Texas coastal plain: Depositional systems, composition, structural development, groundwater flow history and uranium distribution. The University of Texas Bureau of Economic Geology Report of Investigations 87.

Galloway, W. E., Finley, R. J., \& Henry, C. D. (1979). South Texas uranium province geologic perspective. Houston, TX: American Association of Petroleum Geologists National Convention, 1979 Field Trip Guidebook 18.

Galloway, W. E., \& Kaiser, W. R. (1979). Catahoula Formation of the Texas Coastal Plain: Origin, geochemical evolution and characteristics of uranium deposits, GJBX-131(79). Grand Junction: Bendix Field Engineering Corporation.

Goldhaber, M. B., Reynolds, R. L., \& Rye, R. O. (1978). Origin of a South Texas roll-type deposit: II, sulfide petrology and sulfur isotope studies. Economic Geology, 73, 1690-1705.

International Atomic Energy Agency. (1992). Methods for the estimation and economic evaluation of undiscovered uranium endowment and resources-An instruction manual. IAEA Technical Reports Series 344.

International Atomic Energy Agency. (2009). World distribution of uranium deposits (UDEPO) with uranium deposit classification. IAEA-Tecdoc-1629.

International Atomic Energy Agency. (2010). UDEPO database of uranium resources. Vienna: International Atomic Energy Agency.

Olsen, J. A., \& Parker J. R. (1975). PNURE Project Report 14-B, West Gulf Coastal Plains. Grand Junction: U.S. Department of Energy, Regional Potential Evaluation Branch.

Organisation for Economic Cooperation and Development Nuclear Energy Agency and International Atomic Energy Agency. (1996). Uranium 1995: Resources, production and demand. Paris: OECD.

Organisation for Economic Cooperation and Development Nuclear Energy Agency and International Atomic Energy Agency. (2010). Uranium 2009: Resources, production and demand. Paris: OECD.

Organisation for Economic Cooperation and Development Nuclear Energy Agency and International Atomic Energy Agency. (2012). Uranium 2011: Resources, production and demand. Paris: OECD.

Reynolds, R. L., Goldhaber, M. B., \& Carpenter, D. J. (1982). Biogenic and nonbiogenic ore-forming processes in the south Texas uranium district; evidence from the Panna Maria deposit. Economic Geology, 77(3), 541-556.

U.S. Department of Energy. (1980). An assessment report on uranium in the United States of America. U.S. Department of Energy Grand Junction Office, Grand Junction, Colorado, GJO-111(80).

U.S. Department of Energy. (2009). Uranium production and reserves proprietary DOE database, used by USGS under the terms of MOU \#2009686 dated December 24, 2009.

U.S. Department of Labor. (2012). U.S. Bureau of Labor Statistics Consumer Price Index Calculator. Accessed October 25, 2012, from http://www.bls.gov/data/inflation_calculator.htm.

U.S. Energy Information Administration. (2012). U.S. Energy Information Administration Nuclear Glossary. Accessed October 31, 2012, from http://www.eia.gov/tools/glossary/ index.cfm?id=nuclear.

Ux Consulting. (2010). Uranium suppliers annual. Roswell: Ux Consulting Special Report. 